\title{
Distribution and History of Naturalized Common Pear, Pyrus communis, in Ontario
}

\author{
Paul M. CAtLing and Gisèle Mitrow
}

Agriculture and Agri-Food Canada, Environmental Health, Biodiversity, William Saunders Building, Central Experimental Farm, Ottawa, Ontario K1A 0C6 Canada; e-mail: catlingp@agr.gc.ca

Catling, Paul M., and Gisèle Mitrow. 2008. Distribution and history of naturalized Common Pear, Pyrus communis, in Ontario. Canadian Field-Naturalist 122(1): 57-60.

Considered rare or entirely overlooked until 1998, Pyrus communis is currently widespread and locally abundant as an escape from cultivation in southern Ontario. It was first noticed growing wild in Elgin County in 1949 and up until 1965 it was known as a wild plant only in the eastern Lake Erie region. It was first reported in the eastern Lake Ontario region in 1969 and is now widespread and locally abundant there. It now occurs north to the Georgian Bay region, and southwest to Essex County. Since it has had a very effective and rapid dispersal system for centuries as a result of cultivation and discarded cores, the apparently recent spread may be a consequence of climate warming extending the area within which it can grow wild, otherwise it would have escaped much earlier. It occurs in old fields and along fences within agricultural landscapes, but has been recorded in native woodland, prairie and alvar habitats. It dominates abandoned fields and pasture in some areas and may also increase in certain natural habitats and compete with native species. It is, however, less aggressive than some other alien woody plants and provides abundant food in the form of pollen, nectar and fruit during the early stages of old field succession. Spread is believed to be mostly by humans, but Racoons, deer, and other small mammals may be important in local dispersal.

Key Words: Common Pear, Pyrus communis, invasive alien, distribution, naturalized, wild, woody plants, Ontario.

Since the Common Pear (Pyrus communis L.) can grow to a very old age (Catling and Small 2007), planted specimens may last for a long time and may even resprout from old bases. Consequently, planted specimens may appear as escapes in secondary forest and in old fields and around home sites. The status of large old trees as persisting or escaped is thus difficult to determine. Dodge's (1914) report of "several large trees, apparent escapes, along the north shore of Lake Erie" may well have been planted. However, in several parts of Ontario, young pear trees of all ages are spreading through old fields and along fences and even into openings in native woodlands. It is well known that apples spread on their own from cultivated trees or discarded cores, but it is less widely known that pears have done the same thing. In fact some of the basic references to wild plants in Ontario, Trees in Canada (Farrar 1995) for example, fail to mention wild pears. Boivin (1966) indicated naturalized apples across Canada but no naturalized pears. Soper (1949) included Common Pear in his southern Ontario checklist and so did Morton and Venn (1990) in their later checklist, but neither indicated status. Scoggan (1978) noted escape only in Niagara and Welland counties (now Regional Municipality of Niagara) in the eastern Lake Erie region. A number of regional floristic inventories include reference to pears which are presumably wild because these inventories feature plants growing without cultivation. However, the status of wild pears in the province overall was not clear and the impression given is that wild pears are scarce. However, the Ontario plant list (Newmaster et al. 1998) has the status in the province listed as "ORNAMENTAL SE4", meaning escaped from cultivation and common with at least 100 occurrences. Based on recent personal observations this seems to be correct suggesting that the status of Common Pear in Ontario as a wild plant may have changed appreciably over the past few decades. An interest in wild pear germplasm as well as the need for a better understanding of the status and distribution of invasive plant species required a review of wild pears in Ontario.

\section{Methods}

Specimens were examined from various herbaria with good Ontario representation, including CAN, DAO, HAM, LKHD, OAC, QK, TRT, TRTE, UWO and WAT [(acronyms from Index Herbariorum (Holmgren and Holmgren 1998)]. Identifications were checked and label data were recorded and entered into a database. Plants indicated clearly to be "escaped from cultivation" or "not cultivated" were mapped by year to explore distributional history.

\section{Results and Discussion \\ Variation and identification}

At a distance, flowering pears are whiter and have more erect branches (Figure 1) than apples, which are often pinkish and spreading. The flower clusters of pears have a central axis (Figure 1) whereas those of apples have all of the flower pedicels arising at the same point. Pears also tend to have more shiny and leathery leaves. Although all of the wild pears so far examined in Ontario are referable to $P$. communis, 


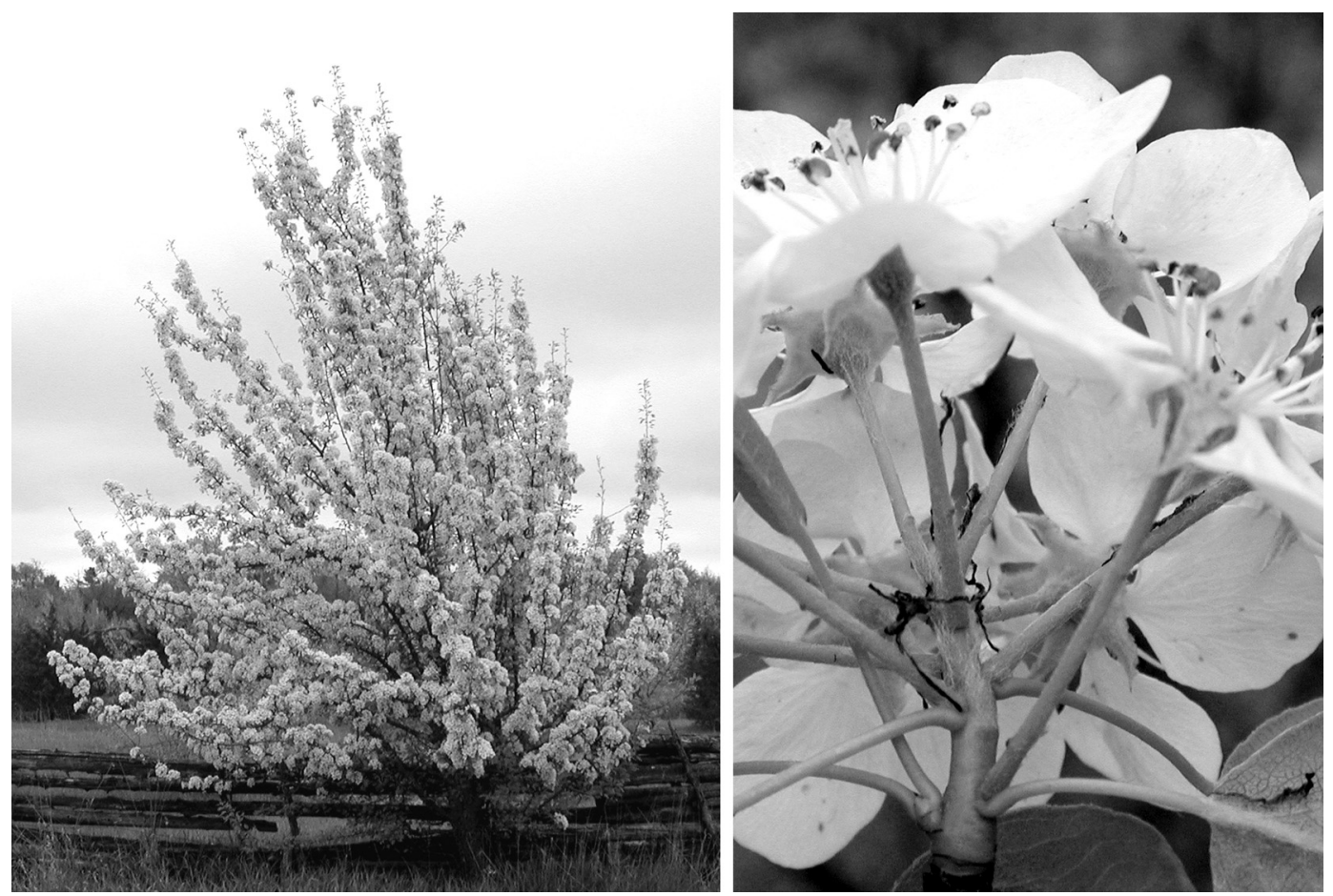

FIGURE 1. Common Pear (Pyrus communis) escaped from cultivation west of Trenton (at $44.18440^{\circ} \mathrm{N}, 76.7669^{\circ} \mathrm{W}$ ), Ontario. A young tree with upright branches is shown on the left. On the right is a portion of an inflorescence showing the elongate main axis of the flower cluster. Photos by P. M. Catling, 13 May 2006.

some of the populations are very variable. On the northeast side of Kingston, where thousands of trees have invaded abandoned pasture, the individual trees have flowers with long reflexed sepals or short spreading sepals, some are thorny while others are not, some have leaves that retain pubescence on both surfaces (but particularly below) until well after flowering whereas others lose all pubescence before fully expanding. This variation is not surprising, given the likely diverse parentage of the trees producing the seeds. Some cultivars are believed to be partly of hybrid origin, including $P$. nivalis Jacq. and other related species (Bell 1990). Callery Pear (Pyrus calleryana Decaisne) is becoming increasingly popular as an ornamental in Ontario. It has not yet been reported as an escape here, although it has become a troublesome escape further south (Nesom 2000; Vincent 2005). It is sold in Ontario nurseries north at least to Kingston. The likelihood of its escape in Ontario is suggested by the fact that it occurs as an escape in zone 6 in Michigan. This zone includes parts of Essex County in extreme southwestern Ontario (Vincent 2005). Pyrus calleryana has flowers with $2-3$ styles instead of 5 as in $P$. communis. The fruit of $P$. calleryana is about $1 \mathrm{~cm}$ in diameter, globose, and blackish-brown with pale dots. The fruit of $P$. communis is $3-10 \mathrm{~cm}$ long, obovoid or pyriform, and yellowish without prominent pale dots.

\section{Distribution and History}

Although P. communis was first cultivated by the Jesuits along the Detroit River in 1705 (Catling and Small 2007), the earliest record of $P$. communis growing wild in Ontario is a collection in 1949 from Yarmouth Township in Elgin County on the label of which collector L. E. James wrote: "thickets and roads escaped from cultivation". This is followed by several collections in 1955 from the wild areas of the Royal Botanical Garden in Hamilton by A. Tamsalu. It was collected elsewhere in the Carolinian region over the next decade, but was still known as a wild plant only from the area of eastern Lake Erie until 1968 (Figure 2 ). Nineteen collections were made in this area of extreme southwestern Ontario prior to the first record from the eastern end of Lake Ontario in 1969, at which time it was considered to be a rare escape (Beschel et al. 1970), but a quarter century later it was still listed as rare in that region (Crowder, et al. 1996). However, our field work in the region, 10 years later, revealed at least 50 localities (defined as $1 \mathrm{~km}$ apart), many with hundreds of trees of all ages and some with more than a thousand trees in a square $\mathrm{km}$. Since Ontario field botanists of the mid-twentieth century were comprehensive in their collection of, and reference to, wildgrowing plants, the preceding indications are considered reliable. For example, where Beschel and his team 

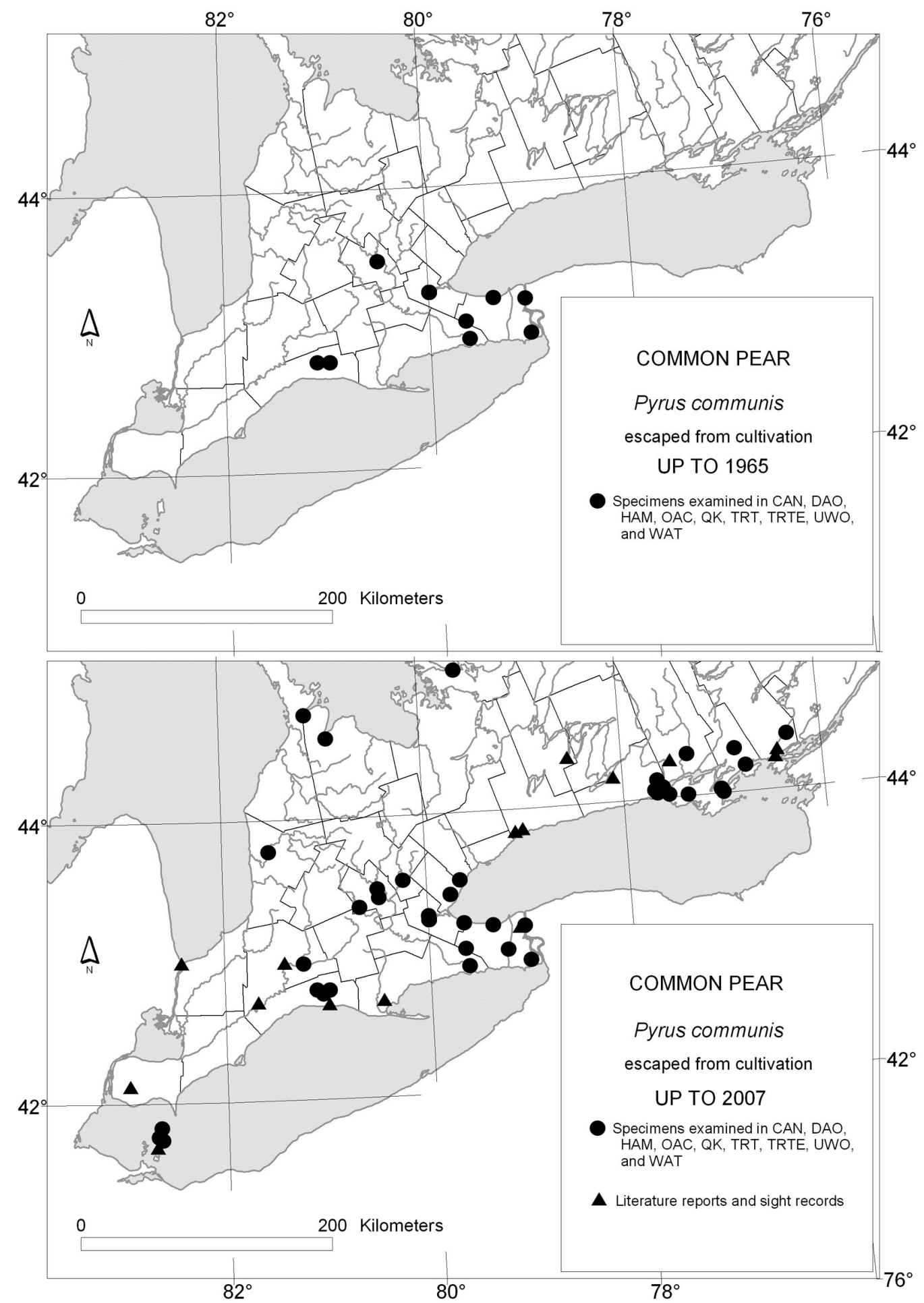

FIGURE 2. Distribution of wild (non-planted) Pyrus communis in Ontario. The dots represent specimens examined in herbarium collections (see methods) whereas the circles indicate literature reports and sight records of the authors and M. J. Oldham. Above, distribution up to 1965 confined to the northeastern Lake Erie region. Below, distribution up to 2007. 
of experts suggest that it was a "rare escape" in the Kingston region in 1970, this is entirely to be trusted. Common Pear was first recorded as a wild plant in the Georgian Bay region from Wiarton and Muskoka in 1974 and 1975, respectively. Its apparently later establishment (after 1965) in more northern areas such as the eastern Lake Ontario region and Georgian Bay may be a consequence of a warming climate recently extending the area within which it can grow wild. This is based on the idea that since it has had a very effective and rapid dispersal system for centuries as a result of introduction, cultivation and discarded cores, it would likely have escaped over a broad region of southern Ontario at a much earlier date if the climate could have been tolerated. Its distribution as currently known includes much of southern Ontario south of the Canadian Shield region (Figure 2).

\section{Ecology and potential impacts}

Common Pear grows well in drought-prone, shallow soils over limestone near Trenton and in Prince Edward County, suggesting substantial drought tolerance. It also occurs in sand, loam and clay soils of neutral to alkaline reaction, but is more often found on drier sites (Catling, personal observation). In most cases, it occurs in old fields and along fences within agricultural landscapes, but has been recorded in native woodland, prairie and alvar habitats. It dominates abandoned fields and pastures in some areas and may also increase in certain natural habitats and competes with native species, but is not considered to be a major threat to native biodiversity at this time. It is less aggressive than some other alien woody plants (Catling 1997; Catling and Mitrow 2005) and provides abundant food in the form of pollen, nectar and fruit during the early stages of old field succession. It is presumably spread mostly by humans as a result of cores discarded by people and plants transported over long distances for cultivation. Dispersal of fruits and seeds by Racoons, Procyon lotor, White-tailed Deer, Odocoileus virginianus, and possibly smaller mammals may be locally important. It is also spread by the nursery trade. These methods of spread can be extremely rapid and its occurrence in Ontario will probably be determined largely by climatic tolerance and substrate rather than factors relating to rate of spread as in many other invasive species.

\section{Acknowledgments}

Brenda Kostiuk assisted with field work. Michael J. Oldham provided sight records and literature reports. Lynn Black assisted with databasing.

\section{Literature Cited}

Bell, R. L. 1990. Pears (Pyrus). Chapter 14. Pages 655-697 in Genetic resources of temperate fruit and nut crops. Edited by J. N. Moore and J. R. Ballington, Jr. Acta Horticulturae (International Sociey of Horticultural Science, Wageningen, Germany) 290.

Beschel, R. E., A. E. Garwood, R. Hainault, I. D. MacDonald, S. P. Van der Kloet, and C. H. Zavitz. 1970 List of the vascular plants of the Kingston region. Queen's University, Kingston, Ontario. 92 pages.

Boivin, B. 1966. Énumération des plantes du Canada - II Lignéedes. Naturaliste canadien 93: 371-437.

Catling, P. M. 1997. The problem of invading alien trees and shrubs: some observations in Ontario and a Canadian checklist. Canadian Field-Naturalist 111: 338-342.

Catling, P. M., and G. Mitrow. 2005. A prioritized list of the invasive alien plants of natural habitats in Canada. Canadian Botanical Association Bulletin 38(4): 55-57.

Catling, P. M., and E. Small. 2007. Cultivated pears in Canada, past \& present. Botanical Electronic News 386: 2-7. http://www.ou.edu/cas/botany-micro/ben/ben386.html

Crowder, A., K. E. J. Topping, and J. C. Topping. 1996. Plants of the Kingston region. Department of Biology, Queen's University, Kingston, Ontario. 123 pages.

Dodge, C. D. K. 1914. Annotated list of flowering plants and ferns of Point Pelee, Ontario, and neighbouring districts. Geological Survey of Canada Memoir 54: 1-131.

Farrar, J. L. 1995. Trees in Canada. Fitzhenry \& Whiteside Limited, Markham, Ontario. 502 pages.

Holmgren, P. K., and N. H. Holmgren. 1998 onwards (continuously updated). Index Herbariorum. New York Botanical Garden, Bronx, New York. Available at: http://sci web.nybg.org/science2/IndexHerbariorum.asp

Morton, K. K., and J. M. Venn. 1990. A checklist of the flora of Ontario vascular plants. University of Waterloo Biological Series Number 34. Waterloo, Ontario 218 pages.

Nesom, G. L. 2000. Callery Pear (Pyrus calleryana - Rosaceae) naturalized in North Carolina. Rhodora 102 (911): 361-364.

Newmaster, S. G., A. Lehela, P. W. C. Uhlig, S. McMurray, and M. J. Oldham. 1998. Ontario plant list. Ontario. Forest Research Institute, Ontario Ministry of Natural Resources (Sault Ste. Marie, Ontario), Forest Research Information Paper 123.

Scoggan, H. J. 1978. The flora of Canada, part 3 - Dicotyledoneae (Saururaceae to Violacaeae). National Museum of Natural Sciences Publications in Botany 7(3): 547-1115.

Soper, J. H. 1949. The vascular plants of southern Ontario. Botany Department, University of Toronto. 95 pages.

Vincent, M. A. 2005. On the spread and current distribution of Pyrus calleryana in the United States. Castanea 70(1): 20-31.

Received 24 April 2007

Accepted 7 November 2008 